\section{Primocane Growth in 'Chester Thornless' Blackberry Trained to the Rotatable Cross-arm Trellis}

Fumiomi Takeda ${ }^{1}$, Ann K. Hummell ${ }^{2}$, and Donald L. Peterson
Appalachian Fruit Research Station, U.S. Department of Agriculture,
Agricultural Research Service, 45 Wiltshire Road, Kearneysville, WV 25430

Additional index words. Rubus, axillary bud, floricane, flower, fruit, inflorescence, lateral branch

\begin{abstract}
A study was conducted to characterize vegetative growth of mature 'Chester Thornless' blackberry plants trained to the rotatable cross-arm (RCA) trellis in which up to six primocanes were retained. Cane emergence occurred from mid-April to lateMay. The first (oldest) primocane attained a sufficient height to be trained in early May in $\mathbf{4 0 \%}$ of plants, but younger primocanes could not be trained until late July. However, only $94 \%, 73 \%, 60 \%$, and $42 \%$ of plants developed three, four, five, and six primocanes, respectively. In primocanes that were trained from 14 May to 3 June, eight or nine medium $(0.7-1.3 \mathrm{~m})$ to long $(>1.3 \mathrm{~m})$ lateral branches developed. Primocanes tied from 4 June to 16 July averaged less than six lateral branches that were mostly of medium and short $(<0.7 \mathrm{~m})$ categories. Primocanes trained after 16 July produced only two short lateral branches. The results indicated that training primocanes from mid-May to mid-June for 'Chester Thornless' blackberry on the RCA trellis would be advantageous to minimize labor costs.
\end{abstract}

Eastern thornless blackberry (Rubus subgenus Rubus Watson) cultivars, such as 'Chester Thornless', 'Hull Thornless', and "I"-shaped hedgerows and on narrow divided canopy trellis systems in the middle Atlantic coast, middle South, lower Midwest, and Pacific Northwest areas of the United States (Galletta et al., 1998). The yield of blackberries is dependent, in part, on the number of bud nodes left on the floricanes after winter pruning (Takeda, 2002). Pruning lateral branches generally decreases yields but often improves fruit quality (Crandall and Daubeny, 1990; Moore and Skirvin, 1990). However, node number per plant is not correlated with yield because not all axillary buds produce a flowering shoot (Takeda, 2002). Yet, yield per floricane remains high in severely pruned plants due to increased budbreak of secondary axillary buds and fruit numbers per raceme. Improved knowledge of the relationship between node number distribution and yield will help determine the best pruning method.

Received for publication 24 June 2002. Accepted for publication 7 Jan. 2003. We thank Eric LeMasters for data collection and plot maintenance work and Scott Wolford for fabrication and installation of trellis posts. Our appreciation is extended to past summer research assistants G. Michael Ball, Kerstyn Haram, Christopher Gillum, and Donald Grove for their valuable assistance. We also thank Barbara L. Bowling, Patrick Byers, Gerard Krewer, and Thomas Tworkoski for reviewing an earlier draft of this manuscript.

${ }^{1}$ Research Horticulturist; to whom reprint request should be addressed. E-mail address: ftakeda@ afrs.ars.usda.gov

${ }^{2}$ Agricultural Science Research Technician.

${ }^{3}$ Agricultural Engineer.
Alternative trellis systems and primocane training techniques are needed in the production of eastern thornless blackberries to maximize yield, minimize labor and to improve machine harvestability (Peterson et al., 1992). A modified, "Y"-shaped trellis (Fig. 1) with a rotatable cross-arm (RCA) was developed to facilitate an over-the-row mechanical harvester (Takeda and Peterson, 1999). Detailed descriptions of trellis components and primocane training 'Triple Crown', are grown commercially on practices for the RCA trellis system are provided elsewhere (Takeda and Peterson, 1999). The RCA trellis, like the Lincoln canopy trellis system (Dunn et al., 1976) and the variations of shift trellis (Stiles, 1999), expands the canopy surface area, spatially separates the floricanes and primocanes into two canopies and potentially improves machine harvest efficiency (Harper et al., 1999; Peterson and Takeda, 2003). Our technique of training primocanes onto the RCA trellis system involves bending and tying the primocane tips as they reach a height of $\approx 1.2 \mathrm{~m}$ onto a training wire that runs through the web of angle iron underneath the short stationary catch arm (Fig. 1). This technique forces the primocanes to grow horizontally in the direction that the mechanical harvester travels. When primocane terminals reach the adjacent plant, the primocanes are tipped. The rationale for training primocanes to grow horizontally is to promote the development of lateral branches from the portion of the primocane that is tied to the training wire at 0.9 -m height. The bending of the main canes also facilitates the rotation of the cross-arm without causing main cane breakage.

Mature plants of 'Chester Thornless' blackberry can produce as many as six or seven primocanes. The canes emerge from the crown of the plant over a 2-month period, beginning in mid-April. The diameters, heights, and numbers of lateral branches that develop from these primocanes are highly variable. If all primocanes are retained, then the need for labor to train them will continue into July and August at the time when fruit is being harvested. Blackberry management strategies that will not conflict with the labor-intensive harvest operation, mitigate labor costs, and help compensate for the scarcity of labor are needed. Bell et al.

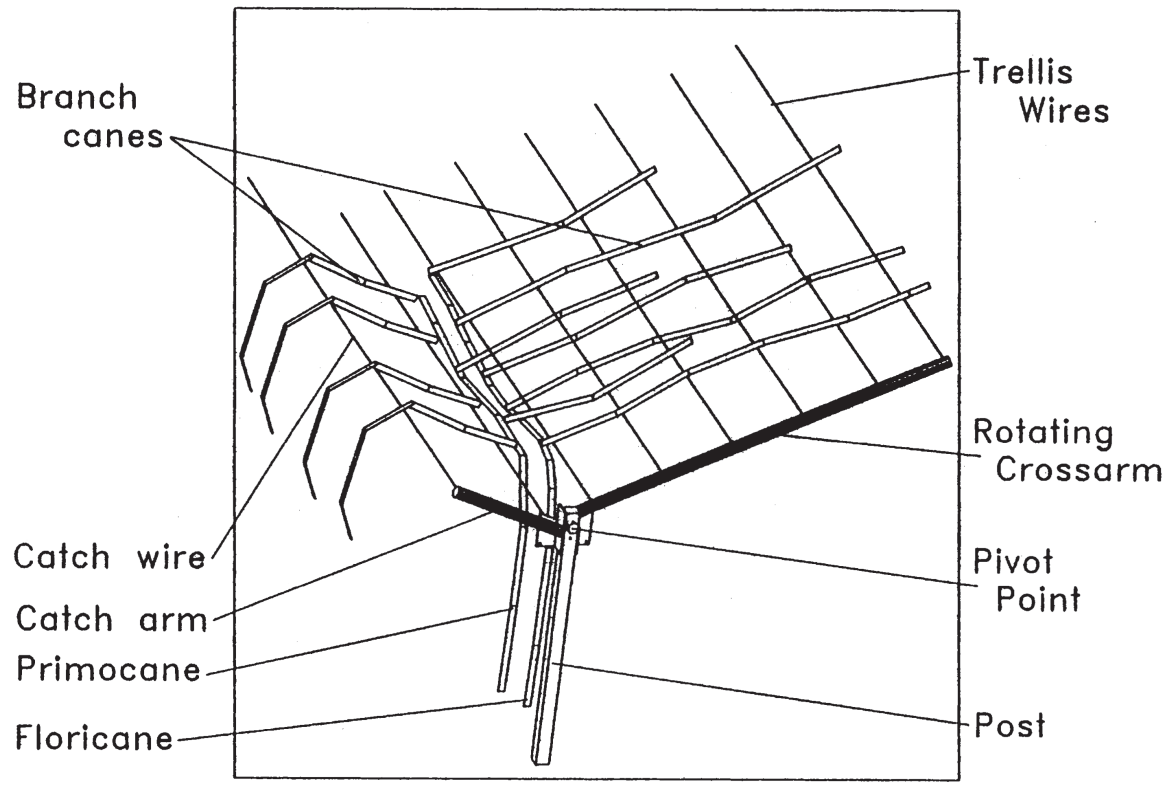

Fig.1. This drawing depicts the positions of floricanes and primocanes on a rotatable cross-arm trellis in July. The main rotating cross-arm has the lateral branches of floricanes tied to its wires and is now positioned for harvesting of fruit that hang below the floricane canopy. Note a primocane has been bent to grow horizontally along the training wire near the pivot point of the rotating cross-arm. Note that the lateral branches have developed from buds along the horizontally growing primocane. All lateral branches that developed from nodes below the bend (basal $0.9 \mathrm{~m}$ of primocane) have been removed. Lateral branch growth is confined by wires on cross-arms within the angle created by the rotating cross-arm and the short stationary catch arm on the other side of the post. 
(1995) and Stanley et al. (1999) reported in trailing 'Marion' and 'Boysen' blackberries, respectively, that plants chemically suckered early in the season subsequently produced primocanes with more lateral branches compared to plants suckered later in the season. In the following season, plants suckered early in the season along with non-suckered control plants produced more berries and had higher yield compared to plants that were suckered late in the season.

The objective of this study was to characterize primocane growth and development in 'Chester Thornless' blackberry trained to the RCA trellis system. The effects of different primocane numbers trained to the RCA trellis system on vegetative and reproductive capacity of 'Chester Thornless' blackberry are described in the companion paper (Takeda et al., 2003)

\section{Materials and Methods}

Plot description. 'Chester Thornless' eastern thornless blackberry plants were established in a replicated block ( 0.4 ha) at the Appalachian Fruit Research Station, Kearneysville, W.Va. $\left(\approx 39^{\circ}\right.$ Nlatitude, elev. $\left.\approx 158 \mathrm{~m}\right)$, in 1991 using tissue-cultured, nursery-matured transplants on a Hagerstown silt loam soil (fine, mixed, Typic Hapludalf). The ground had an $\approx 3 \%$ slope. Plants were set in rows oriented in a north-south direction more or less following the slope at a $1.3 \mathrm{~m} \times 4 \mathrm{~m}$ spacing. Plants were trained to a rotatable cross-arm (RCA) trellis (Takeda and Peterson, 1999). The plot maintenance and pest control followed the published bramble production guidelines for the region (Goulart et al., 1991; Demchak, 2000). Plants received annual fertilizer applications $\left(\mathrm{kg} \cdot \mathrm{ha}^{-1}\right)$ of $45 \mathrm{~N}-19.6 \mathrm{P}-37.4 \mathrm{~K}$ in April and supplemental drip irrigation when required in June, July, and August.

Primocane growth characterization. In 1998, eight 4-plant plots of 'Chester Thornless' blackberries were randomly chosen for a study to characterize the growth and development of as many as six primocanes per plant. Primocanes that emerged from the plant crown were trained to grow vertically to $1.2 \mathrm{~m}$. When the tips of the primocanes were $\approx 0.2 \mathrm{~m}$ beyond the training wire located at $0.9 \mathrm{~m}$ (Takeda and Peterson, 1999), they were tied to the wire. The distal ends of the primocanes were then bent and tied to the wire to orient their subsequent shoot extension in the horizontal direction towards the adjacent plant. Thereafter, cane tying was performed at weekly intervals until the primocanes had grown an additional $\approx 1.25$ $\mathrm{m}$ in length, at which time they were tipped. Primocanes were tagged with surveyor's flagging tapes of various colors to distinguish the first (oldest) to the sixth (youngest) primocanes tied to the RCA trellis system. The week on which they were tied to the training wire was recorded. All lateral branches that developed below the bend ( $0.9 \mathrm{~m}$ aboveground) on the primocane were counted and removed during the growing season. In the fall, primocane diameters at $30 \mathrm{~cm}$ from the soil line, number of nodes, and the number of lateral branches

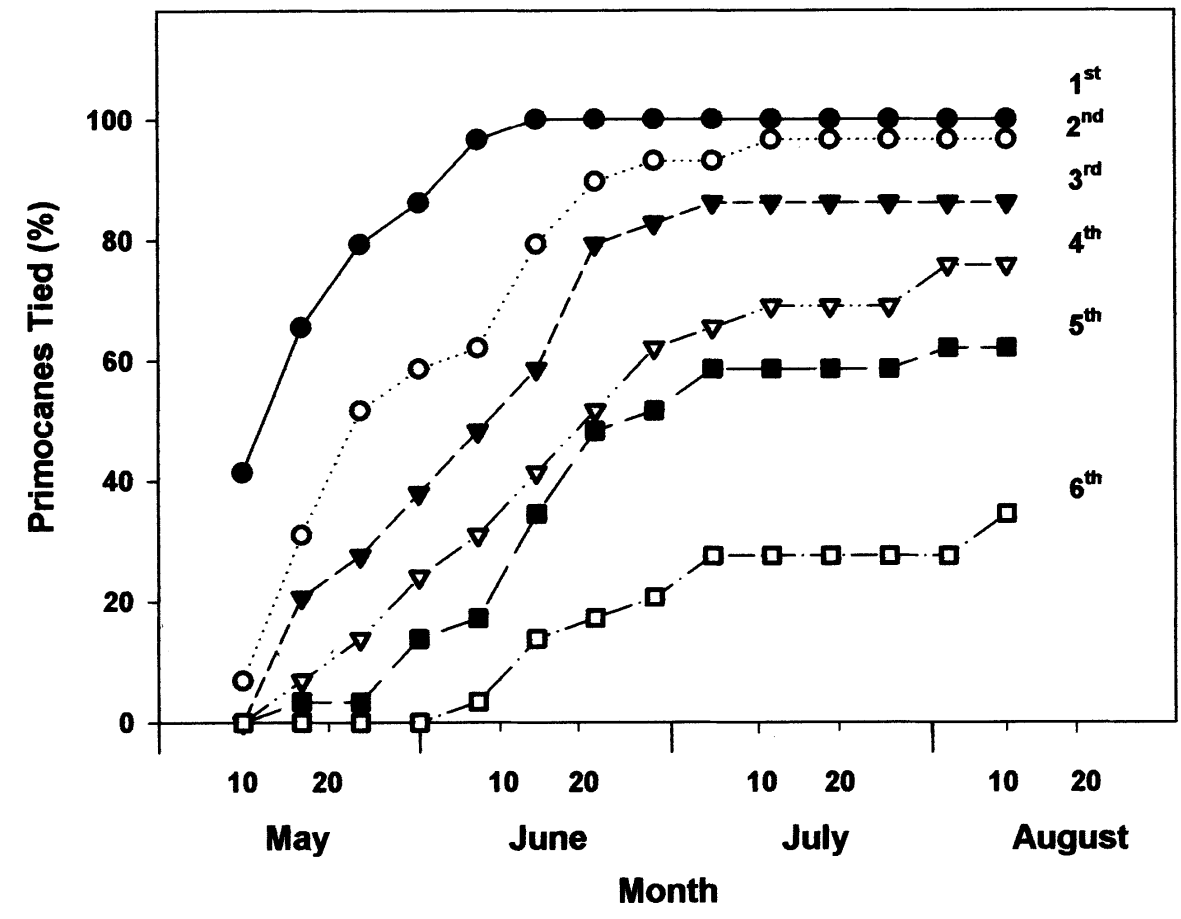

Fig. 2. Developmental chronology of the first to sixth primocanes of 'Chester Thornless' blackberry plants. Values on the lines indicate the percentage of plants $(n=32)$ with primocanes that reached $1.2 \mathrm{~m}$ and tied to the training wire on the RCA trellis from May to Aug. 1998.

Table 1. The measurements of vegetative growth parameters in six primocanes of 'Chester Thornless' blackberry in 1998, in the order of tying to RCA trellis.

\begin{tabular}{lcccc}
\hline & $\begin{array}{c}\text { Cane diam } \\
(\mathrm{mm})\end{array}$ & $\begin{array}{c}\text { Below the bend } \\
(\text { vertical })\end{array}$ & $\begin{array}{c}\text { Beyond the bend } \\
\text { (horizontal) }\end{array}$ & $\begin{array}{c}\text { Budbreak } \\
(\%)\end{array}$ \\
\hline Primocane & $21.2 \mathrm{a}^{\mathrm{x}}$ & $5.2 \mathrm{a}$ & $10.0 \mathrm{a}$ & $60 \mathrm{a}$ \\
First & $19.4 \mathrm{a}$ & $4.1 \mathrm{~b}$ & $7.1 \mathrm{~b}$ & $47 \mathrm{ab}$ \\
Second & $16.8 \mathrm{~b}$ & $3.0 \mathrm{c}$ & $6.0 \mathrm{~b}$ & $40 \mathrm{bc}$ \\
Third & $15.7 \mathrm{~b}$ & $2.2 \mathrm{c}$ & $4.7 \mathrm{c}$ & $31 \mathrm{c}$ \\
Fourth & $15.1 \mathrm{~b}$ & $2.1 \mathrm{c}$ & $5.8 \mathrm{bc}$ & $35 \mathrm{c}$ \\
Fifth & $14.2 \mathrm{~b}$ & $2.7 \mathrm{c}$ & $4.4 \mathrm{c}$ & $43 \mathrm{bc}$ \\
Sixth & & &
\end{tabular}

${ }^{2}$ Respectively, number of lateral shoots developed from axillary buds below the bend in primocanes for training on wire at 1-m height and removed, and lateral branches in the horizontal portion of primocane and retained for fruit production.

${ }^{y}$ Average of two caliper measurements taken at $30 \mathrm{~cm}$ above the soil line.

${ }^{\mathrm{x}}$ Mean separation within columns by Duncan's multiple range test, $P<0.05$.

that developed in the horizontal portion of each floricane above the bend were recorded. Each lateral branch was categorized as long $(>1.3 \mathrm{~m})$, medium $(0.7-1.3 \mathrm{~m})$, or short $(<0.7$ $\mathrm{m})$. The following spring, the total number of nodes and flowering shoots on each lateral branch were determined.

Statistical design and analysis. The experiments were conducted using a randomized complete-block experimental design with eight 4-plant replications. Percentage data were transformed to square root-arcsin prior to statistical analysis. Data were subjected to PROC MIXED (SAS Institute, Cary, N.C.). Statistical significance was evaluated at $P \leq 0.05$.

\section{Results and Discussion}

Primocane emergence time was highly variable among the plants. In 1998, primocanes began to emerge from the ground in mid-April. Cane tying and training onto the RCA trellis system began in mid-May and continued until late July (Fig. 2). By 11 May, the oldest primocane in nearly $40 \%$ of plants had reached more than $1 \mathrm{~m}$ and was sufficiently tall for tip bending and tying to the training wire. The tying of the oldest primocane in remaining plants was completed in late June. After the first primocane was tied, second, third, fourth, fifth, and sixth primocanes became trainable in succession, if they were present (Fig. 2). The sixth primocane was tied from early June until late July. The number of canes that developed on each plant was highly variable as well. Although most plants developed two trainable primocanes, the percentage of plants that developed three, four, five, or six primocanes declined to $86 \%, 76 \%$, $62 \%$, and $35 \%$, respectively (Fig. 2).

Vegetative growth measurements for the six primocanes trained to the RCA trellis and lateral branches that developed along the horizontal portion of primocanes are presented in Tables 1,2 , and 3 . Among the six primocanes, the first (i.e., oldest) primocane was the most vigorous and produced the greatest amount of growth, 
Table 2. Vegetative characteristics of long, medium, and short lateral branches that developed on the primocanes of 'Chester Thornless' blackberry in 1998.

\begin{tabular}{lcccc}
\hline $\begin{array}{l}\text { Lateral } \\
\text { branches }\end{array}$ & $\begin{array}{c}\text { Diam } \\
(\mathrm{mm})\end{array}$ & $\begin{array}{c}\text { Length } \\
(\mathrm{m})\end{array}$ & $\begin{array}{c}\text { Nodes } \\
(\text { no. })\end{array}$ & $\begin{array}{c}\text { Tertiary } \\
\text { branch canes }\end{array}$ \\
\hline Long & $12.2 \mathrm{a}^{\mathrm{z}}$ & $2.1 \mathrm{a}$ & $40 \mathrm{a}$ & $3 \mathrm{a}$ \\
Medium & $9.2 \mathrm{~b}$ & $1.1 \mathrm{~b}$ & $25 \mathrm{~b}$ & $1 \mathrm{~b}$ \\
Short & $7.2 \mathrm{c}$ & $0.6 \mathrm{c}$ & $18 \mathrm{c}$ & $0 \mathrm{c}$ \\
\hline
\end{tabular}

${ }^{\mathrm{z}}$ Mean separation within columns by Duncan's multiple range test, $P<$ 0.05 .

Table 3. Lateral branch development in the horizontally oriented section of primocanes trained to the RCA trellis, and number of nodes and flowering shoots counted on the lateral branches the following spring, in the order of tying in 1998.

\begin{tabular}{llccccc}
\hline & \multicolumn{9}{c}{ No. lateral branches } & & Buds & $\begin{array}{c}\text { Flowering } \\
\text { shoots } \\
\text { Primocane }\end{array}$ & Long & Medium & Short & Broken & & (no./floricane) & (no./floricane) \\
\cline { 2 - 5 } First & $5.0 \mathrm{a}^{\mathrm{z}}$ & $2.7 \mathrm{a}$ & $1.2 \mathrm{a}$ & $1.1 \mathrm{a}$ & $220 \mathrm{ab}$ & $69 \mathrm{ab}$ \\
Second & $3.8 \mathrm{~b}$ & $1.9 \mathrm{~b}$ & $0.8 \mathrm{a}$ & $0.6 \mathrm{a}$ & $246 \mathrm{a}$ & $90 \mathrm{a}$ \\
Third & $2.0 \mathrm{c}$ & $2.1 \mathrm{~b}$ & $1.5 \mathrm{a}$ & $0.4 \mathrm{a}$ & $180 \mathrm{ab}$ & $57 \mathrm{ab}$ \\
Four & $1.4 \mathrm{c}$ & $1.6 \mathrm{c}$ & $1.2 \mathrm{a}$ & $0.5 \mathrm{a}$ & $124 \mathrm{~b}$ & $41 \mathrm{~b}$ \\
Fifth & $1.8 \mathrm{c}$ & $2.2 \mathrm{~b}$ & $1.5 \mathrm{a}$ & $0.5 \mathrm{a}$ & $161 \mathrm{ab}$ & $60 \mathrm{ab}$ \\
Sixth & $1.4 \mathrm{c}$ & $1.4 \mathrm{c}$ & $0.8 \mathrm{a}$ & $0.8 \mathrm{a}$ & $118 \mathrm{~b}$ & $34 \mathrm{~b}$ \\
\hline
\end{tabular}

${ }^{7}$ Mean separation within columns by Duncan's multiple range test, $P<0.05$. Values in column without letters are not significantly different from each other.

as indicated by larger cane diameter and more numerous and longer lateral branches below and beyond the bend at $\approx 1 \mathrm{~m}$. Cane diameter ranged from $30 \mathrm{~mm}$ for the largest primocane to $<15 \mathrm{~mm}$ for the smallest primocane. Lateral branch numbers below the bend ranged from five in the oldest to less than three in the sixth (i.e., youngest) primocane. Primocanes tied later in the season had reduced vegetative growth capacity. The percentage of buds above the bend that broke to form lateral branches ranged from $51 \%$ in the oldest primocane to less than $40 \%$ in the youngest primocanes that were trained later in season (Table 1).

Bending the primocanes promoted lateral branch development in the portion of primocanes oriented horizontally. In contrast, we have observed that if primocanes are trained to a trellis to maintain their upright growth habit, then typically, several lateral branches eventually emerge from buds in the leaf axils on the main cane (Takeda and Hummell, unpublished data). Emergence of lateral branches occurs first at nodes near the ground and progresses acropetally. In unpruned primocanes maintained in an upright orientation, twice as many lateral branches developed in the basal $1-\mathrm{m}$ portion as in the more distal portions of the primocane (data not presented). Hedging the primocanes just above the post or cross-arm height in summer is a recommended cultural practice for blackberries to confine the fruiting zone to a manageable height, release the lateral buds from apical control, and promote lateral branching (Moore and Skirvin, 1990). In this study, the combination of the bending of the primocane to reorient its extension growth in the horizontal plane and removal of apical control by tipping probably eliminated the strong apical dominance of the shoot tip over the axillary buds in more proximal node positions. As a result, increased lateral shoot development occurred from the axillary buds all along the horizontal portion of the primocane. The promotion of lateral branch development by bending and tipping the primocanes appears to be greater than that obtained by summer hedging.

Once the primocane extension growth was oriented in a horizontal direction, the emergence of lateral branches occurred first near the bend and then towards the tip. Taking into account the number of lateral branches of the three length classes and the average node numbers on them (Table 2), the contribution by long, medium, and short lateral branches towards potential flower cluster production on the oldest primocane was calculated to be $68 \%$, $31 \%$, and $8 \%$, respectively. This suggested that cane management techniques should be used to increase the number of vigorous lateral branches and numbers of axillary buds from which flowering shoots develop, thus improving the yield potential.

Along with an increased number of lateral branches, older primocanes developed more longer- and medium-length lateral branches than the younger primocanes (Table 3 ). The oldest primocanes developed nearly eight longand medium-length $(>0.7 \mathrm{~m})$ lateral branches while the youngest primocane developed less than three. The total node number among lateral branches on the oldest primocane was 220, while the total node number for lateral branches of the sixth primocane was only 118 (Table 3 ). In the following spring (1999), flowering shoots on lateral branches of the oldest floricanes and youngest floricanes numbered 69 and 34, respectively (Table 3 ). These results indicated that the fruiting capacity of the primocanes trained after mid-June would be less and their contribution to plant productivity would be slight compared to those primocanes trained in May. Furthermore, not all plants produced more than three primocanes (Fig. 2). Those primocanes trained after mid-June produced fewer lateral branches (Table 1) and flowering shoots (Table 3 ).

'Black Satin' plants trained to a wide "V" trellis and tipped at 2.8-m height produce about four lateral branches per meter of primocane length (Takeda, 2002). In this study, 'Chester Thornless' blackberry trained on the RCA trellis system produced as many as eight lateral branches per meter of primocane length in the horizontally oriented section. Also, the removal of lateral branches below the bend could have contributed to increased lateral branch growth in the portion of primocanes oriented horizontally. For example, in 'Navaho' blackberry plants, which were trained upright, primocanes typically reached $2.0 \mathrm{~m}$ in height and produced about three long lateral branches in the basal 0.7-m section (Takeda and Hummell, unpublished data). However, less than one lateral cane developed in the distal $2 / 3$ portions. In contrast, when all branches in the basal portion were removed as they emerged, primocanes grew $2.5 \mathrm{~m}$ tall and developed about three 1-m long lateral branches in the distal portions.

Takeda (2002) reported that sufficient growth and development of lateral branches on the primocanes was needed to attain high plant productivity. The cane management technique utilized in this study was different from those used in earlier studies (Goulart and Demchak, 1993; Stiles, 1999; Swartz et al., 1984; Takeda, 2002), in that it took advantage of the fact that divided canopy trellises increase fruit production. Improved light conditions for primocanes achieved by divided canopies or an alternate-year production system may promote axillary branching. Also, it was apparent that primocane bending to force their growth in a horizontal direction negated the apical control by the shoot tip over the axillary buds in more proximal positions. This cane manipulation significantly improved the development of lateral branches in eastern thornless blackberries.

When sufficient numbers of long- and medium-length lateral branches were present then the retention of only two or three primocanes that emerge from the crown early in the season would produce adequate yields. In fact, increasing cane numbers to six primocanes improved yields by only $18 \%$ in 2000 , because many of the primocanes that were trained late in the season developed only a few or no long or medium length branch canes for training onto the RCA trellis (Takeda et al., 2003).

The cane-bending technique used on 'Chester Thornless' blackberry to promote lateral branch development is not adaptable for all blackberry cultivars for training on the RCA trellis system, because of their varied cane development characteristics. For example, primocane bending is not the preferred method of cane training for cultivars such as 'Navaho', which are typically established $<0.5 \mathrm{~m}$ apart in the row because they are prolific primocane producers and tend to develop primocanes that are $>2 \mathrm{~m}$ tall. Instead, when 'Navaho' blackberry is trained to RCA trellis, primocanes are tied to the training wire only to maintain their upright extension growth and lateral branches that emerge from nodes below the training wire are removed. After harvest, tall primocanes are tied to wires on the rotatable cross-arm and other canopy manipulations are performed, as 
previously described for 'Chester Thornless', to position all fruit on one side of the canopy. High productivity is maintained because of their capacity to produce as many as fifteen 2.5-m-tall primocanes per meter of row length (Takeda and Hummell, unpublished data). This primocane growth characteristic is highly desirable when adapting blackberries to the RCA trellis system, because it eliminates the labor for primocane bending and tipping.

In summary, the development of primocanes and lateral branches on 'Chester Thornless' plants trained to the RCA trellis system was characterized. Primocane emergence from the crown occurred from mid-April to late-June and they were trained and tied to the RCA trellis from May to August. Almost all plants produced two or three primocanes, but only about one-third of the plants produced as many as six primocanes. Primocanes that emerged and trained early were vigorous and produced many long lateral branches, while those primocanes that became trainable after mid-June tended to be less vigorous and produced fewer and mostly weak lateral branches. Flower shoot production in the following spring ranged from as many as 90 on primocanes trained in May to as few as 34 on primocanes trained in July and August. Thus, the earlyemerging primocanes have a greater reproductive capacity than those primocanes trained late in the summer. These findings should be valuable in the development of management strategies that will promote the growth and development of early-emerging primocanes, not conflict with the labor-intensive harvest operation, reduce labor costs, and improve the economic viability of this crop.

\section{Literature Cited}

Bell, N.C., B.C. Strik, and L.W. Martin. 1995. Effect of primocane suppression date on 'Marion' trailing blackberry. I. Yield components. J.Amer. Soc. Hort. Sci. 120:21-24.

Crandall, P.C. and H.A. Daubeny. 1990. Raspberry management, p. 157-213. In: G.J. Galletta and D.G. Himelrick (eds.). Small fruit crop management. Prentice Hall, Englewood Cliffs, N.J.

Demchak, K. 2000. Commercial berry production and pest management guide, 2000-2001. Pa. State Univ., Coll. Agr. Sci. AGRS 53.

Dunn, J.S., M. Stolp, and G.G. Lindsay. 1976. Mechanical raspberry harvesting and the Lincoln canopy system. Amer. Soc. Agr. Eng., St. Joseph, Mich. Paper 76-1543.

Galletta, G.J., A.D. Draper, J.L. Maas, R.M. Skirvin, A.G. Otterbacher, H.J. Swartz, and C.K. Chandler. 1998. 'Chester Thornless'blackberry. Fruit Var. J. 52:118-123.

Goulart, B.L., M. Brittingham, J. Harper, P. Heinemann, W. Hock, E. Rajotte, J. Rytter, and J. Travis. 1991. Small fruit production and pest management guide, 1991-92. Pa. State Univ., Coll. Agr. Sci. AGRS 53.

Goulart, B.L. and K. Demchak. 1993. Physiological responses of "T", "V" and hedgerow trained red and black raspberries (Rubus idaeus $\mathrm{L}$. and $R$. occidentalis L.). Acta Hort. 352:159-167.

Harper, J.K., F. Takeda, and D.L. Peterson. 1999 Economic evaluation of improved mechanical harvesting system for eastern thornless blackberries. Appl. Eng. Agr. 15:597-603.

Moore, J.N. and R.M. Skirvin. 1990. Blackberry management, p. 214-244. In: G.J. Galletta and D.G. Himelrick (eds.). Small fruit crop management. Prentice Hall, Englewood Cliffs, N.J.

Peterson, D.L. and F. Takeda. 2003. Feasibility of mechanically harvesting fresh market quality eastern thornless blackberry. Appl. Eng. Agr. 19:25-30.

Peterson, D.L., F. Takeda, and T. Kornecki. 1992. Harvester for "T", "V", and "Y" trellised eastern thornless blackberries. Appl. Eng. Agr. 8: 9-12.

Stanley, C.J.,P.M. Harris-Virgin, C.G.T. Morgan, and A.M. Snowball. 1999. Boysenberry primocane management for improved productivity. Acta Hort. 505:79-86.

Stiles, H.D. 1999. Limited arm-rotation shift-trellis (LARS) and primocane management apparatus (PMA) for raspberries and blackberries (Rubus cvs. or crops). Virginia Agr. Expt. Sta. Bul. 991. Blacksburg.

Swartz, H.J., S.E. Gray, L.W. Douglas, E. Durner, C.S. Walsh, and G.J. Galletta. 1984. The effect of divided canopy trellis design on thornless blackberry. HortScience 19:533-535.

Takeda, F. 2002. Winter pruning affects yield components in 'Black Satin' eastern thornless blackberry. HortScience 37:101-103.

Takeda, F., A.K. Hummell, and D.L. Peterson. 2003. Effects of cane number on yield components in 'Chester Thornless' blackberry trained on the rotatable cross-arm trellis. HortScience 38 377-380.

Takeda, F. and D.L. Peterson. 1999. Considerations for machine harvesting fresh-market eastern thornless blackberries: Trellis design, cane training systems, and mechanical harvester developments. HortTechnology 9: $16-21$. 